\title{
EVALUATION OF GROWTH AND YIELD PERFORMANCES OF NAPIER GRASS CULTIVAR PAKCHONG-1 UNDER DIFFERENT SPACIAL PATTERNS IN THE KILINOCHCHI DISTRICT, SRI LANKA
}

\author{
Duglas Sathees $^{1 *}$ and Sivajanani Santhiralingam ${ }^{2}$ \\ ${ }^{1}$ Department of Biosystems Technology, Faculty of Technology, University of Jaffna, Sri Lanka \\ ${ }^{2}$ Department of Animal Science, Faculty of Agriculture, University of Jaffna, Sri Lanka \\ *Corresponding Author: duglas@univ.jfn.ac.lk ( iD https://orcid.org/0000-0001-8873-5148) \\ Received: 09.09.2021; Accepted: 31.12.2021; Published: 31.01.2022
}

\begin{abstract}
Inadequacy of quality forage production is a major limiting factor for dairy production in the Sri Lankan dry zone. Napier grass cv Pakchong-1 (Pennisetum purpureum x Pennisetum glaucum) is a tropical grass with fastgrowing and high yielding ability. The study aims to determine the growth parameters and yield performance of Pakchong-1 grass under three different spacing of $30 \mathrm{~cm} \times 30 \mathrm{~cm}, 90 \mathrm{~cm} \times 90 \mathrm{~cm}$ and $120 \mathrm{~cm} \times 90 \mathrm{~cm}$ in the Kilinochchi district, dry zone of Sri Lanka, from April 2019 to March 2020. A complete randomized design with three replicates was used in this study. Growth parameters were measured bi-weekly up to the 8th week and harvested the foliage after the 8th week in 56 days intervals. Plants at $30 \mathrm{~cm} \times 30 \mathrm{~cm}$ spacing have shown the highest plant height of $(153.00 \mathrm{~cm})$, the higher number of leaves (93.67), longer leaf length $(95.33 \mathrm{~cm})$, wider leaf width $(3.82 \mathrm{~cm})$ and higher leaves per tiller (11.33) at 8 weeks after planting $(P<0.05)$. While the highest $(P<0.05)$ the number of tillers $(10.00)$ was recorded at $120 \mathrm{~cm} \times 90 \mathrm{~cm}$ spacing. Fresh matter yields were highest $(P<0.05)$ at $30 \mathrm{~cm} \times 30 \mathrm{~cm}$ spacing in all cutting frequencies. The second cutting at the 14th week has shown the highest fresh matter yield $(P<0.05)$ in all spacing. Pakchong -1 can be suggested for the Sri Lankan dry zone regions at $30 \mathrm{~cm} \times 30 \mathrm{~cm}$ spacing to provide the highest fresh matter output and optimal growth performance.
\end{abstract}

Keywords: Dry Matter, Growth parameters, Kilinochchi district, Pakchong-1 (Pennisetum purpureum $\times$ Pennisetumglaucum )

\section{INTRODUCTION}

Successful forage production is one of the crucial factors for any ruminant production. Still, some problems need to be addressed concerning the feed for livestock in Sri Lanka(Pushparajah and Sinniah, 2018a). Especially, the availability of forage crop fields amongst all other agricultural fields as farmers so concerned about the cultivation of cereals and industrial crops (Gnanagobal and Sinniah, 2018). One of the reasons for the lesser dairy productivity of livestock in Sri Lanka could be the lack of quality forages and their availability. Feeding with good quality and adequate quantity of green fodder materials for dairy animals is essential to maximize milk production(Premaratne and Premalal, 2006).

At present, the Sri Lanka dairy industry predominantly depends on forage materials from natural pasture fields and fodder collected from on the roadside, mountain slopes, tank banks, uncultivated public and private lands. Only a handful of farmers turned to grow quality pasture and fodder solely for their dairy animals in Sri Lanka. Lack of availability, accessibility of quality improved pasture, fodder and availability of cultivable lands for pasture and fodder are some of the major constraints prevailing in dairy production of Sri Lanka.

Inadequate quality forage and the lower availability of forage materials is the critical limiting factor for livestock production in many developing countries. The introduction of high yielding forages will overcome these problems. King Napier Grass (P. purpureum X P.americanum) is a well known perennial forage crop, having a higher growth rate, higher green matter productivity and desirable nutritive value. The development of new hybrid Napier grasses is undergoing to increase its agronomic performance suiting the demand of high performing dairy cows. One such hybrid Napier grass cultivar is Pakchong- 1, which was developed by crossing P.purpureum and $P$. glaucum in Thailand.

Pakchong-1 showed a faster growth rate, resulting in a higher yield with an elevated Phosphorus content to adopt a wide range of environmental conditions. Until this time, very little research has been done in Pakchong - 1 in Sri Lanka and very 
little data are available for Pakchong - 1 cultivation in the northern regions of Sri Lanka. Moreover, yield, digestibility and nutrient composition must be taken into consideration for selecting forage species. Therefore, this study was developed to investigate the performances of growth and yield of Pakchong-1 under selected three different plant spacing in the Kilinochchi district, the northern part of Sri Lanka.

\section{METHODOLOGY}

This experiment was carried out at the Faculty of Technology, University of Jaffna, Ariviyal Nagar, Kilinochchi from April 2019 to March 2020. This area lies in the dry zone of Sri Lanka and the latitudinal and the longitude coordinates of the field location are 9031'40" $\mathrm{N}$ and 80039'82" E respectively. The soil type is red yellow latosol.

The field experiment was carried out using a randomized complete block design (RCBD) with the selected three plant spacings of $30 \mathrm{~cm} \times 30 \mathrm{~cm}$, $90 \mathrm{~cm} \times 90 \mathrm{~cm}$ and $120 \mathrm{~cm} \times 90 \mathrm{~cm}$ that commonly farmers practised in this region. Each treatment was replicated three times. Pakchong -1 cuttings were obtained from the Livestock and Poultry Farm, Department of Animal Science, Faculty of Agriculture, Ariviyal Nagar, Kilinochchi. Single nodal cuttings were planted per planting hole and irrigation was done at weekly intervals. After 30 days of planting manual weeding was done

From each plot randomly three plants avaoiding the border lines of the experiment plots were selected at the field for taking measurements. The number of tillers per clump, the total number of leaves, number of leaves per tiller, length of the standard leaf of a tiller and its width and basal stem diameter were recorded at weekly intervals from two weeks after planting. After 60 days of planting plants were cut at $15 \mathrm{~cm}$ from ground level and ratoon crop was maintained.

Immediately after harvesting the fresh weight of forage, was taken using a spring balance. Harvested fresh forage ( $2 \mathrm{~kg}$ of the sample) from each plot were allowed to be air-dried for 24 hours. Then the air-dried samples were allowed to be oven-dried at $750 \mathrm{C}$ for 72 hours to obtain a constant dry matter weight. Similarly, the harvested forage yield was obtained at 60 days intervals between the 2nd, 3rd, 4 th and 5th harvests and the fresh matter yield was calculated nearly calendar cycle.

Data were analyzed statistically using the statistical software SAS 9.1.3. Mean separation was done using Duncan's multiple ranges test with a p-value of $<0.05$.

\section{RESULTS AND DISCUSSION}

\section{Growth characteristics}

The effects of row spacing and on plant height, number of leaves per plant, leaf length $\&$ leaf width of a standard leaf on the tiller, tiller number and diameter and leaf number per tiller are presented in Table 1, Table 2, Table 3, Table 4 and Table 5 respectively per plant at 14 days, 28 days, 42 days and 56 days after planting.

For plant height followed the order $30 \mathrm{~cm} \times$ $30 \mathrm{~cm}>90 \mathrm{~cm} \times 90 \mathrm{~cm}>120 \mathrm{~cm} \times 90 \mathrm{~cm}$ row spacing, while number of leaves and standard leaf with for the spacing $30 \mathrm{~cm} \times 30 \mathrm{~cm}$ greater than for $90 \mathrm{~cm} \times 90 \mathrm{~cm}$ and $120 \mathrm{~cm} \times 90 \mathrm{~cm}$ spacing $(\mathrm{P}<0.05)$. Row spacing had significant effects on plant height, number of leaves per plant, leaf length $\&$ leaf width of a standard leaf on the tiller, tiller number and diameter and leaf number per tiller with reduced spacing $(\mathrm{P}<0.05)$.

Reduced row spacing had a significant effect on number of leaves/tiller $(30 \mathrm{~cm} \times 30 \mathrm{~cm}>90 \mathrm{~cm} \times$ $90 \mathrm{~cm}>120 \mathrm{~cm} \times 90 \mathrm{~cm}, \mathrm{P}<0.05)$ and leaves $/$ plant $(30 \mathrm{~cm} \times 30 \mathrm{~cm}>90 \mathrm{~cm} \times 90 \mathrm{~cm}>120 \mathrm{~cm} \times 90 \mathrm{~cm}$, $\mathrm{P}<0.05$.According to table 1 the height of the Pakchong - 1 was higher $(\mathrm{P}<0.05)$ in the $90 \mathrm{~cm} \times$ $90 \mathrm{~cm}$ spacing at the 14 daysafter planting but by the 56 daysafter planting the height at $30 \mathrm{~cm} \times 30 \mathrm{~cm}$ spacing was the highest $(\mathrm{P}<0.05)$. The results obtained by (Wangchuk et al., 2015) indicated that the height at 60 days after planting was $218 \mathrm{~cm}$. The difference may be due to the climatic conditions prevailing in the areas.

Table 2 presents the number of leaves per plant at different spacing on at 14 days, 28 days, 42 days and56 days after planting. The highest number of leaves per plant was obtained for $30 \mathrm{~cm} \times 30 \mathrm{~cm}$ at 56 days after planting in respect to the other two spacing. A field study(Samarawickrama et al., 2018)in Peradeniyaat the 42 days after planting reported a lower number of leaves (51) with different spacing. The leaves count per plant are very important as the leaves have a higher nutritive value than the stem (Sarmini and Premaratne, 2017).

The average length of the Pakchong-1 was not different among the spacing at 28 days and 42 daysafter planting. The highest $(\mathrm{P}<0.05)$ leaf length was observed at the 56 daysafter planting for spacing $30 \mathrm{~cm} \times 30 \mathrm{~cm}$.Individual plant survival is influenced by large leave length within a sward. On the other hand, plant growth is also interpreted 
by an increased leaf length of the plants. (Pushparajah and Sinniah, 2018b). In the present study the highest $(\mathrm{P}<0.05)$ leaf width was observed at $30 \mathrm{~cm} \times 30 \mathrm{~cm}$ spacing at the 56 days after planting.

Table 5 presents the number of tillers per plant at 14 days, 28 days, 42 days and56 daysafter planting. There is no significant difference between the spacing at 14 days but 28 daysand 42 days have a significant difference between the three spacing. The number of tillers at $120 \mathrm{~cm} \times 90 \mathrm{~cm}$ was higher $(\mathrm{P}<0.05)$ at the 14 days, 28 days, 42 days and56 daysafter planting. The number of tillers per clump observed in the current studyat $90 \mathrm{~cm} \times 90 \mathrm{cmas}$ per the values obtained by (Samarawickrama et al., 2018).

Table 1: Reasons for abandoning paddy farming

\begin{tabular}{|c|c|c|c|c|}
\hline & \multicolumn{4}{|c|}{ Height of the Plant $(\mathrm{cm})$} \\
\hline Spacing & 14 days & 28 days & 42 days & 56 days \\
\hline $30 \mathrm{~cm} \times 30 \mathrm{~cm}$ & $40.55 \pm 0.39^{b}$ & $57.11 \pm 0.38^{b}$ & $79.22 \pm 0.51^{\mathrm{a}}$ & $153.00 \pm 1.76^{\mathrm{a}}$ \\
\hline $90 \mathrm{~cm} \times 90 \mathrm{~cm}$ & $42.11 \pm 0.77^{\mathrm{d}}$ & $57.11 \pm 0.84^{\mathrm{b}}$ & $75.56 \pm 1.35^{\mathrm{b}}$ & $143.56 \pm 1.35^{b}$ \\
\hline $120 \mathrm{~cm} \times 90 \mathrm{~cm}$ & $39.22 \pm 0.39^{\mathrm{b}}$ & $58.67 \pm 0.67^{\mathrm{a}}$ & $68.78 \pm 0.38^{\mathrm{c}}$ & $131.44 \pm 3.53^{\mathrm{c}}$ \\
\hline
\end{tabular}

Means $($ Mean \pm SD) in the same column followed by different superscripts differ significantly at $\mathrm{P}<0.05$

Table 2: Effect of row spacing on the number of leaves per plant at 14 days, 28 days, 42 days and56 days after planting.

\begin{tabular}{ccccc}
\hline & \multicolumn{3}{c}{ Number of leaves } \\
\hline Spacing & 14 days & 28 days & 42 days & 56 days \\
$30 \mathrm{~cm} \times 30 \mathrm{~cm}$ & $25.44 \pm 0.7^{\mathrm{a}}$ & $37.11 \pm 1.35^{\mathrm{a}}$ & $64.78 \pm 0.84^{\mathrm{a}}$ & $93.67 \pm 0.33^{\mathrm{a}}$ \\
$90 \mathrm{~cm} \times 90 \mathrm{~cm}$ & $25.97 \pm 0.95^{\mathrm{a}}$ & $37.78 \pm 2.17^{\mathrm{a}}$ & $62.67 \pm 2.00^{\mathrm{a}}$ & $89.00 \pm 1.73^{\mathrm{b}}$ \\
$120 \mathrm{~cm} \times 90 \mathrm{~cm}$ & $27.85 \pm 0.27^{\mathrm{a}}$ & $39.44 \pm 1.28^{\mathrm{a}}$ & $63.33 \pm 2.65^{\mathrm{a}}$ & $89.11 \pm 1.13^{\mathrm{b}}$ \\
\hline
\end{tabular}

Means (Mean \pm SD) in the same column followed by different superscripts differ significantly at $\mathrm{P}<0.05$

Table 3: Effect of row spacing on leaf length at 14 days, 28 days, 42 days and56 days after planting.

\begin{tabular}{ccccc}
\hline & \multicolumn{3}{c}{ Leaf length $(\mathrm{cm})$} \\
\hline Spacing & 14 days & 28 days & 42 days & 56 days \\
$30 \mathrm{~cm} \times 30 \mathrm{~cm}$ & $12.86 \pm 0.51^{\mathrm{b}}$ & $38.0 \pm 0.58^{\mathrm{a}}$ & $59.67 \pm 1.00^{\mathrm{a}}$ & $95.33 \pm 1.76^{\mathrm{a}}$ \\
$90 \mathrm{~cm} \times 90 \mathrm{~cm}$ & $14.02 \pm 0.43^{\mathrm{b}}$ & $37.56 \pm 0.19^{\mathrm{a}}$ & $59.33 \pm 1.15^{\mathrm{a}}$ & $90.78 \pm 0.51^{\mathrm{b}}$ \\
$120 \mathrm{~cm} \times 90 \mathrm{~cm}$ & $16.08 \pm 0.94^{\mathrm{a}}$ & $39.22 \pm 1.35^{\mathrm{a}}$ & $59.22 \pm 0.69^{\mathrm{a}}$ & $90.56 \pm 0.69^{\mathrm{b}}$ \\
\hline
\end{tabular}

Means (Mean \pm SD) in the same column followed by different superscripts differ significantly at $\mathrm{P}<0.05$

Table 4: Effect of row spacing on leaf width at 14 days, 28 days, 42 days and56 daysafter planting.

\begin{tabular}{ccccc}
\hline & \multicolumn{4}{c}{ Leaf width $(\mathrm{cm})$} \\
\hline Spacing & 14 days & 28 days & 42 days & 56 days \\
$30 \mathrm{~cm} \times 30 \mathrm{~cm}$ & $0.7 \pm 0.1^{\mathrm{b}}$ & $2.63 \pm 0.06^{\mathrm{a}}$ & $3.31 \pm 0.13^{\mathrm{a}}$ & $3.82 \pm 0.05^{\mathrm{a}}$ \\
$90 \mathrm{~cm} \times 90 \mathrm{~cm}$ & $1.17 \pm 0.15^{\mathrm{a}}$ & $2.61 \pm 0.07^{\mathrm{a}}$ & $3.30 \pm 0.06^{\mathrm{a}}$ & $3.52 \pm 0.04^{\mathrm{b}}$ \\
$120 \mathrm{~cm} \times 90 \mathrm{~cm}$ & $1.10 \pm 0.10^{\mathrm{a}}$ & $2.64 \pm 0.02^{\mathrm{a}}$ & $3.29 \pm 0.05^{\mathrm{a}}$ & $3.57 \pm 0.06^{\mathrm{b}}$ \\
\hline
\end{tabular}

Means (Mean \pm SD) in the same column followed by different superscripts differ significantly at $\mathrm{P}<0.05$

Table 5: Effect of row spacing on the number of tillers per plantat 14 days, 28 days, 42 days and 56 daysafter planting.

\begin{tabular}{|c|c|c|c|c|}
\hline & \multicolumn{4}{|c|}{ Number of tillers per plant } \\
\hline & 14 days & 28 days & 42 days & 56 days \\
\hline $30 \mathrm{~cm} \times 30 \mathrm{~cm}$ & $1.56 \pm 0.2^{\mathrm{a}}$ & $4.22 \pm 0.51^{\mathrm{c}}$ & $5.89 \pm 0.19^{c}$ & $8.44 \pm 0.19^{b}$ \\
\hline $90 \mathrm{~cm} \times 90 \mathrm{~cm}$ & $1.53 \pm 0.35^{\mathrm{a}}$ & $4.67 \pm 0.33^{b}$ & $6.89 \pm 0.39^{b}$ & $8.56 \pm 0.19^{b}$ \\
\hline $120 \mathrm{~cm} \times 90 \mathrm{~cm}$ & $2.02 \pm 0.07^{\mathrm{a}}$ & $5.22 \pm 0.19^{\mathrm{a}}$ & $7.78 \pm 0.19^{a}$ & $10.0 \pm 0.58^{\mathrm{a}}$ \\
\hline
\end{tabular}

Means (Mean \pm SD) in the same column followed by different superscripts differ significantly at $\mathrm{P}<0.05$

Table 6: Effect of row spacing on leaves per tiller at 14 days, 28 days, 42 days and 56 daysafter planting.

\begin{tabular}{ccccc}
\hline & \multicolumn{4}{c}{ Number of leaves per tiller } \\
\hline Spacing & 14 days & 28 days & 42 days & 56 days \\
$30 \mathrm{~cm} \times 30 \mathrm{~cm}$ & $3.33 \pm 0.58^{\mathrm{b}}$ & $9.11 \pm 1.35^{\mathrm{a}}$ & $11.22 \pm 0.38^{\mathrm{a}}$ & $11.33 \pm 0.33^{\mathrm{a}}$ \\
$90 \mathrm{~cm} \times 90 \mathrm{~cm}$ & $1.67 \pm 0.58^{\mathrm{c}}$ & $8.22 \pm 0.19^{\mathrm{a}}$ & $9.22 \pm 0.38^{\mathrm{b}}$ & $10.56 \pm 0.19^{\mathrm{b}}$ \\
$120 \mathrm{~cm} \times 90 \mathrm{~cm}$ & $5.0 . \pm 0.00^{\mathrm{a}}$ & $7.78 \pm 0.19^{\mathrm{a}}$ & $8.33 \pm 0.33^{\mathrm{c}}$ & $9.11 \pm 0.69^{\mathrm{c}}$ \\
\hline
\end{tabular}

Means (Mean \pm SD) in the same column followed by different superscripts differ significantly at $\mathrm{P}<0.05$ 


\section{Forage yield production}

The effects of row spacing on leaf and stem fresh matter yield production are presented in Table 7. Fresh matter yield at 3rd cutting was greater for Pak-chong-1 but declined sharply as the row space increased with the greatest effect for Pakchong-1 $(\mathrm{P}<0.05)$. Amongst the main effects, row spacing had a significant effect on fresh matter production $(30 \mathrm{~cm} \times 30 \mathrm{~cm}>90 \mathrm{~cm} \times$ $90 \mathrm{~cm}>120 \mathrm{~cm} \times 90 \mathrm{~cm})$.
As complementary information, correlations between growth parameters are presented in Table 7. While fresh matter yield was positively correlated with plant height, tiller number, leaf number and width, plant height . On the other hand, fresh matter yield was negatively correlated with row spacing.

When considering the fresh matter yields, the highest yields were obtained at the third harvest for the $30 \mathrm{~cm} \times 30 \mathrm{~cm}$ spacing.

Table 7: Effect of row spacing on fresh matter yield (ton/ha/year) at different cutting frequencies.

\begin{tabular}{cccccc}
\hline & \multicolumn{4}{c}{ Number of harvests } \\
\hline Spacing & 1 & 2 & 3 & 5 & 4 \\
$30 \mathrm{~cm} \times 30 \mathrm{~cm}$ & $63.00 \pm 2.00^{\mathrm{a}}$ & $89.33 \pm 2.52^{\mathrm{a}}$ & $107.33 \pm 2.52^{\mathrm{a}}$ & $85.67 \pm 1.53^{\mathrm{b}}$ & $71.33 \pm 1.53^{\mathrm{a}}$ \\
$90 \mathrm{~cm} \times 90 \mathrm{~cm}$ & $60.67 \pm 1.53^{\mathrm{a}}$ & $80.33 \pm 2.08^{\mathrm{b}}$ & $95.00 \pm 1.00^{\mathrm{b}}$ & $82.00 \pm 1.00^{\mathrm{ab}}$ & $71.33 \pm 1.53^{\mathrm{a}}$ \\
$120 \mathrm{~cm} \times 90 \mathrm{~cm}$ & $59.20 \pm 2.00^{\mathrm{a}}$ & $75.00 \pm 1.00^{\mathrm{b}}$ & $91.33 \pm 2.08^{\mathrm{b}}$ & $79.33 \pm 1.53^{\mathrm{c}}$ & $71.00 \pm 1.00^{\mathrm{a}}$ \\
\hline
\end{tabular}

Means (Mean \pm SD) in the same column followed by different superscripts differ significantly at $\mathrm{P}<0.05$

\section{Discussion}

Plant height as a growth parameter is a result of elongation of the stem internodes, which is influenced by the environment as suggested by Hozumi et al. . In the current study, taller plants were observed with narrow spacing, which is in agreement with reports in the literature that narrower spacing will give taller plants as a result of competition for sunlight (Lamana M.C.L., 2003) . Taller plants led to narrower stem diameter as well.

Leaf development has been described extensively for fodders, as growth is mostly reflected in large increase in leaf length as plants grow to maturity, accompanied by relatively small increase in width and thickness (Skinner R.H. et al 1994). Large leave lengths are also important for the survival of individual plants within a sward (Barre P. et al 2015).

Significant reduction in dry matter yield with increasing plant spacing may be due to decreasing plant density with increasing spacing. In a study conducted at Kemptville Research Station, Canada (Ashraf T. et al 2014), planting density had a significant effect on fresh and dry matter production and two higher densities had significantly higher production than the 2 lower densities for 3 sweet sorghum hybrids including Sugar graze.

Plant spacing has a marked impact on the efficiency of use of land, light, water and nutrients. By optimising plant spacing, highest yield potential can be achieved from the smallest possible area (Oseni T.O. et al 1986).

\section{CONCLUSIONS}

The study suggests that the growth parameters and yield of Pakchong-1 grass under three different spacing in the Kilinochchi district, dry zone of Sri Lanka showed that $30 \mathrm{~cm} \times 30 \mathrm{~cm}$ spacing has shown the highest $(\mathrm{P}<0.05)$ plant height of $153.00 \mathrm{~cm}$, higher number of leaves $(93.67)$, longer leaf length of $95.33 \mathrm{~cm}$, wider leaf width of $3.82 \mathrm{~cm}$ and higher leaves per tiller (11.33) at 56 days after planting. While the highest $(\mathrm{P}<0.05)$ the number of tillers (10.00) was recorded at $120 \mathrm{~cm} \times 90 \mathrm{~cm}$ spacing. Fresh matter yields were highest $(\mathrm{P}<0.05)$ at $30 \mathrm{~cm} \times 30 \mathrm{~cm}$ spacing in all cutting frequencies. The second cutting at the 98 days has shown the highest $(\mathrm{P}<0.05)$ fresh matter yield in all spacing. Thus, Pakchong -1 can be recommended to dry zone of Sri Lanka at the spacing of $30 \mathrm{~cm} \times 30 \mathrm{~cm}$ to obtain a higher fresh matter yield and best growth performance.

\section{REFERENCES}

Ashraf, T. and Alessandro, S. 2014. Effects of planting density and genetics on production of sweet sorghum. Poster presented at the Northeast Agricultural and Biological Engineering Conference (NABEC), Kemptville, 27-30 July.

Barre, P., Turner, L.B., Gutierrez, A.J.E. 2015. Leaf length variation in perennial forage grasses (Review). Agriculture. 5:682-96.

Gnanagobal, H. and Sinniah, J. 2018. Evaluation of growth parameters and forage yield of Sugar Graze and Jumbo Plus sorghum hybrids under three different spacings during the maha season in the dry zone of Sri Lanka. Tropical 
Grasslands-Forrajes Tropicales, 6(1), p. 34. doi: $10.17138 / \operatorname{tgft}(6) 33-41$.

Hozumi, E, Weston, R.H., Hesketh, J. 1965. Factors limiting the intake of feed by sheep: studies with wheat hay. Aust J Agric Res. 1965; 18:983-1002.

Lamana, M.C.L. 2003. Effect of spacing between plants on growth and forage yield of two maize (Zea mays L.) cultivars. Masters Dissertation. University of Khartoum.

Oseni, T.O. and Fawusi, M.O. 1968. Influence of nursery spacing and plant arrangement on growth and leaf nutrient content of three citrus root stock seedlings. Trop Agric. 64(1):41.

Premaratne, S. and Premalal, G.G.C. 2006. 'Hybrid Napier (Pennisetum perpureum X Pennisetum americarnum) VAR. CO-3: a resourceful fodder grass for dairy development in Sri Lanka', Journal of Agricultural Sciences, 2(1), p. 22. doi: 10.4038/jas.v2i1.8110.

Pushparajah, S. and Sinniah, J. 2018a. Evaluation of dry matter yield and nutritive value of Sugar graze and Jumbo plus at different spacing in the yala season in the dry zone of Sri Lanka. Agriculture and Food Security, 7(1). doi: 10.1186/s40066-018-0172-6.

Pushparajah, S. and Sinniah, J. 2018b. Evaluation of dry matter yield and nutritive value of Sugar graze and Jumbo plus at different spacing in the yala season in the dry zone of Sri Lanka. Agriculture and Food Security, 7(1), pp. 1-6. doi: 10.1186/s40066-018-0172-6.

Samarawickrama, L. L. et al. 2018. Yield, Nutritive Value and Fermentation Characteristics of Pakchong-1 (Pennisetum Purpureum $\times$ Pennisetum Glaucum) in Sri Lanka. Sljap, 10(September 2020).

Sarmini, M. and Premaratne, S. 2017. Yield and nutritional quality potential of three fodder grasses in the Northern region of Sri Lanka. Tropical Agricultural Research, 28(2), p. 175. doi: $10.4038 /$ tar.v28i2.8194.

Skinner, R.H. and Nelson, C.J. 1994. Role of leaf appearance rate and the coleoptiles tiller in regulating tiller production. Crop Sci. 34:71-5.

Wangchuk, K. et al. 2015. Forage growth, yield and quality responses of Napier hybrid grass cultivars to three cutting intervals in the Himalayan foothills. Tropical GrasslandsForrajes Tropicales, 3(3), pp. 142-150. doi: 10.17138/TGFT(3)142-150. 